\title{
Detection of Panulirus argus Virus 1 in Caribbean spiny lobsters
}

\author{
Megan M. Montgomery-Fullerton ${ }^{1}$, Roland A. Cooper ${ }^{1}$, Kathryn M. Kauffman ${ }^{1}$, \\ Jeffrey D. Shields ${ }^{2}$, Robert E. Ratzlaff ${ }^{1, *}$
}

\author{
${ }^{1}$ Department of Biological Sciences, MGB 110, Old Dominion University, Norfolk, Virginia 23529-0266, USA \\ ${ }^{2}$ Virginia Institute of Marine Science, The College of William and Mary, Gloucester Point, Virginia 23062, USA
}

\begin{abstract}
Panulirus argus Virus 1 (PaV1) is a pathogenic virus that infects Caribbean spiny lobsters $P$. argus in the Florida Keys. We have developed a PCR detection assay for PaV1 for the purpose of studying the natural history of the virus and for monitoring the prevalence of infection. The detection of the virus in hemolymph and other tissues is based on the PCR amplification of a $499 \mathrm{bp}$ product using specific primers designed from a cloned fragment of the PaV1 genome. The sensitivity limit for the assay was $1.2 \mathrm{fg}$ of purified viral DNA. The PaV1 primers did not react with lobster DNA, oyster DNA, Ostreid Herpesvirus 1, or murine cytomegalovirus. Using this assay, we successfully followed the course of infection in lobsters inoculated with PaV1 and we detected infections in wild-caught lobsters from the Florida Keys. We have also established guidelines for interpreting infection results from the PCR assay for PaV1.
\end{abstract}

KEY WORDS: Assay $\cdot$ Lobster virus $\cdot$ Panulirus argus $\cdot$ Molecular detection

\section{INTRODUCTION}

In 1999, a pathogenic and lethal virus was discovered in juvenile Caribbean spiny lobsters Panulirus argus in the Florida Keys, Florida, USA (Shields \& Behringer 2004). The virus, P. argus Virus 1 (PaV1), infects hyalinocytes and semigranulocytes in hemolymph, as well as the spongy connective tissues of the hepatopancreas and other tissues. The ensuing disease develops in 1 to 3 mo and is characterized by the loss of hemocytes and clotting activity with the appearance of viral particles in the hemolymph. There is also a visible change in the hemolymph from clear or bluish to a white milky color, which is diagnostic for infection. In addition to changes in hemolymph characteristics, the reserve inclusion cells in the hepatopancreas are depleted of glycogen, and the hepatopancreas exhibits focal necrosis, ischemia, and atrophy, which leads to metabolic wasting and lethargy in heavily infected lobsters (Shields \& Behringer 2004)
$\mathrm{PaV} 1$ has the characteristics of a DNA virus and shares some morphological characteristics of both the Herpesviridae and the Iridoviridae (Shields \& Behringer 2004). Infected cells have enlarged and irregularly shaped nuclei, with densely packed, emarginated chromatin. Virions develop in the nucleus and are icosahedral with toroid bodies, $182 \mathrm{~nm}$ in diameter.

Initial diagnosis of the disease has been based on changes in host behavior and appearance, including the development of cloudy hemolymph, yellowing of background carapace color, fouling of the carapace, lethargy, and an increase in solitary occupancy of dens (Behringer et al. 2006). Confirmation of viral infection has been based on histopathological disease manifestations and the presence of viral DNA in tissues by a FISH (fluorescence in situ hybridization) assay (Li et al. 2007) and by culture-based methods (Li \& Shields 2007). Here, we report a specific and sensitive PCR (polymerase chain reaction) assay that can detect PaV1 in the early stages of infection using a small hemolymph sample from live Panulirus argus. 


\section{MATERIALS AND METHODS}

Lobsters. Juvenile spiny lobsters Panulirus argus were collected in the Florida Keys from shallow (1 to $2 \mathrm{~m}$ ) sub-tidal habitats, by hand using SCUBA, and transported in seawater-filled coolers to the Keys Marine Laboratory, Long Key, Florida, USA. Lobsters were shipped overnight to the Virginia Institute of Marine Science, Virginia, USA, where they were held in 781 aquaria equipped with aerators and 2 Whisper filters containing preconditioned crushed coral. Artificial seawater (Marinemix Forty Fathoms, Marine Enterprises International) in the aquaria was monitored weekly for $\mathrm{pH}$ (7.1 to 7.6), salinity (33 to $35 \mathrm{ppt})$, temperature $\left(21\right.$ to $\left.24^{\circ} \mathrm{C}\right)$, ammonia $(<1.0 \mathrm{ppm})$, and nitrite $(<1.0 \mathrm{ppm})$, and $50 \%$ water changes were performed to maintain water quality within acceptable limits. Lobsters were fed squid 3 times per week, and any food remaining in aquaria after $3 \mathrm{~h}$ was removed. Healthy individuals have been maintained in this system for $>2 \mathrm{yr}$. Diseased and healthy animals, distinguished by the presence of discolored hemolymph and obvious signs of morbidity, were housed in separate aquaria in different rooms. The virus has been maintained for $>3 \mathrm{yr}$ in the laboratory through repeated passages of infected hemolymph into healthy animals.

All hemolymph samples from healthy, naturally infected, and inoculated lobsters were collected in an equal volume of citrate anticoagulant (Söderhäll \& Smith 1983) and frozen at $-80^{\circ} \mathrm{C}$ until tested. The stock anticoagulant solution also contained $20 \%$ dimethyl sulfoxide (Sigma-Aldrich), $0.8 \%$ protease inhibitor cocktail (Sigma-Aldrich P8340), and 10 IU bacitracin $\mathrm{ml}^{-1}$ (Fisher Scientific). For inoculation trials, pre-inoculation hemolymph was collected from each lobster immediately prior to needle inoculation with $0.1 \mathrm{ml}$ of pooled, infected hemolymph from 3 diseased lobsters mixed
1:1 in anticoagulant. In preliminary tests, the injection of our stock anticoagulant solution alone did not visibly harm lobsters. Post-inoculation hemolymph was collected and frozen starting on Day 10 and at various intervals over the subsequent 2 mo.

DNA extraction. Genomic DNA was extracted from samples for PCR from $\sim 40 \mu$ of hemolymph (diluted 1:1) and $25 \mathrm{mg}$ of tissue using a QIAamp DNA Mini Extraction kit (Qiagen) according to the manufacturer's protocol. Anticoagulant and double-distilled water $\left(\mathrm{ddH}_{2} \mathrm{O}\right)$ served as negative controls for the DNA extraction procedure. A pCR4TOPO plasmid (Invitrogen) containing an 892 bp sequence (p892) cloned from purified PaV1 served as a positive control specific for the PaV1 primers (GenBank Accession Number EF206313). Extracted DNA levels from hemolymph were $5 \pm 3 \mu \mathrm{g} \mathrm{ml}^{-1}$ as determined by fluorometric assay using Sybr Green II (Corbett et al. 2004, Smilkstein et al. 2004) with salmon sperm DNA as the standard.

Primers. Using the p892 sequence, specific primers for PaV1 were designed using the DNA calculator (www.sigma-genosys.com/calc/DNACalc.asp) and the SDSC Biology workbench (http://workbench.sdsc. $\mathrm{edu} /$ ). The following criteria were applied to design new primers: GC content from 45 to $60 \%$, minimal secondary structure, no primer dimers, $T_{\mathrm{m}}$ between 50 and $70^{\circ} \mathrm{C}$, and length of 20 to 24 bases. The various primers in the present study were used to detect PaV1, OsHV1 (Ostreid Herpesvirus 1), and herpes viruses in general, as well as the plasmid pCR4TOPO (Table 1).

PCR assay. The reagents in each reaction tube used for the PCR assay for PaV1 were based on an Invitrogen PCR kit: $1 \times$ buffer, $1.5 \mathrm{mM} \mathrm{MgCl}_{2}, 0.2 \mathrm{mM}$ dNTPs, $0.5 \mu \mathrm{M}$ for each primer, $1 \mathrm{U}$ of Taq DNA polymerase, and $5 \mu \mathrm{l}$ of template containing $\sim 25 \mathrm{ng}$ of DNA in a total volume of $50 \mu \mathrm{l}$. The reactions were run on an MJ Research thermal cycler (Bio-Rad Laboratories). The amplification conditions were $94^{\circ} \mathrm{C}$ for $10 \mathrm{~min}$, followed by

Table 1. Primers used in the present study. PaVI: Panulirus argus Virus 1; OsHVI: Ostreid Herpesvirus 1; r1 and r2: Round 1 and 2 , respectively

\begin{tabular}{|c|c|c|c|c|}
\hline \multirow[t]{2}{*}{ ID } & \multirow[t]{2}{*}{ Primer sequence $\left(5^{\prime} \rightarrow 3^{\prime}\right)$} & \multicolumn{2}{|c|}{$\longrightarrow$ PCR $\longrightarrow$} & \multirow[t]{2}{*}{ Source } \\
\hline & & Specificity & Product size (bp) & \\
\hline $45 \mathrm{aF}$ & TTCCAGCCCAGGTACGTATC & \multirow[t]{2}{*}{$\mathrm{PaV} 1, \mathrm{r} 1$ and r2 } & \multirow[t]{2}{*}{499} & \multirow[t]{2}{*}{ Present study } \\
\hline $543 a R$ & AACAGATTTTCCAGCAGCGT & & & \\
\hline OsC5F & CCG TGACTTCTATGGGTATGTCAG & \multirow[t]{2}{*}{ OsHV1, r1 } & \multirow[t]{2}{*}{765} & \multirow[t]{4}{*}{ Batista et al. (2005) } \\
\hline OsC13R & CCTCGAGGTAGCTTTTGTCAA & & & \\
\hline OsC2F & СТСТTTACCATGAAGATACCCACC & \multirow[t]{2}{*}{ OsHV1, r2 } & \multirow[t]{2}{*}{352} & \\
\hline OsC4R & GCAGTTGTGGTATACTCGAGATTG & & & \\
\hline DFA & GAYTTYGCNAGYYTNTAYCC & \multirow[t]{2}{*}{ Herpes viruses, r1 } & \multirow[t]{2}{*}{$\sim 745$} & \multirow[t]{2}{*}{ Elhers et al. (1999) } \\
\hline KG1 & GTCTTGCTCACCAGNTCNACNCCYTT & & & \\
\hline M13F & GTAAAACGACGGCCAG & \multirow[t]{2}{*}{ p305 (pCR4TOPO) } & \multirow[t]{2}{*}{481} & \multirow[t]{2}{*}{ Invitrogen K4575-J10 } \\
\hline M13R & CAGGAAACAGCTATGAC & & & \\
\hline
\end{tabular}


30 cycles of $94^{\circ} \mathrm{C}$ for $30 \mathrm{~s}, 51^{\circ} \mathrm{C}$ for $30 \mathrm{~s}$, and $72^{\circ} \mathrm{C}$ for $1 \mathrm{~min}$, with a final extension of $72^{\circ} \mathrm{C}$ for $10 \mathrm{~min}$. After several preliminary tests of a single-round PCR with $\geq 30$ cycles, we found that the resolution of the $499 \mathrm{bp}$ PaV1 band compared to the background improved when a 2-round PCR was employed. Thus, $5 \mu$ of the first 30 cycle round PCR reaction product was used as the template in the second round of PCR under the same conditions, resulting in a $499 \mathrm{bp}$ amplicon in both rounds. All PCR results shown are Round 2 reactions unless otherwise noted. The PCR for OsHV1 (Batista et al. 2005) and a PCR that broadly detects herpes viruses based on their DNA polymerase genes (Elhers et al. 1999) were run according to published methods.

To establish that extracted hemolymph samples did not contain PCR reaction inhibitors as a potential source of false-negative readings, we spiked $5 \mu$ of the hemolymph DNA extract with $50 \mathrm{ng}$ of a pCR4TOPO plasmid (Invitrogen) containing a 305 bp insert unrelated to PaV1 (p305). The PaV1 primers were replaced with plasmid-specific M13 primers that yielded a $481 \mathrm{bp}$ amplicon. The annealing temperature was adjusted to $49^{\circ} \mathrm{C}$ for 30 cycles with all other conditions similar to the PCR assay for PaV1. All PCR products were electrophoresed in $1.5 \%$ agarose for $\sim 45 \mathrm{~min}$ at a constant $6 \mathrm{~V} \mathrm{~cm}^{-1}$. Each lane was loaded with $0.5 \mu \mathrm{l}$ $\mathrm{mm}^{-2}$ of the nominal area at the bottom of a well to standardize loading volumes among the various sized gel combs used in the present study.

\section{RESULTS}

The PCR assay for PaV1 was highly sensitive for the virus using the $45 \mathrm{aF}$ and $543 \mathrm{aR}$ primer set (Fig. 1). The DNA from purified PaV1 was titrated in a 2-round PCR, where Lane 9 showed the $499 \mathrm{bp}$ band at the lower detection limit of $1.2 \mathrm{fg}$. Comparing the 2 rounds, the intensities of the $499 \mathrm{bp}$ band increased in Round 2 at each concentration of PaV1 DNA and the sensitivity improved 100-fold.

The quantity of lobster genomic DNA necessary to detect PaV1 in hemolymph was estimated for the PCR assay by titration using DNA from an inoculated lobster Panulirus argus (Fig. 2). We selected a minimally infected juvenile lobster that appeared healthy, although it was not possible to determine its actual viral load. Strong bands were generated at $499 \mathrm{bp}$, from 12 to 0.012 ng of genomic DNA (Lanes 4 to 7 ). In all subsequent PCR assays for PaV1, a test sample that did not amplify had to contain $\geq 1.5 \mathrm{ng}$ of DNA in Round 1 (125-fold the genomic DNA end point) to be considered negative for the virus.

We also tested the specificity of the PCR assay for PaV1 against 2 known herpes viruses (Fig. 3). Neither

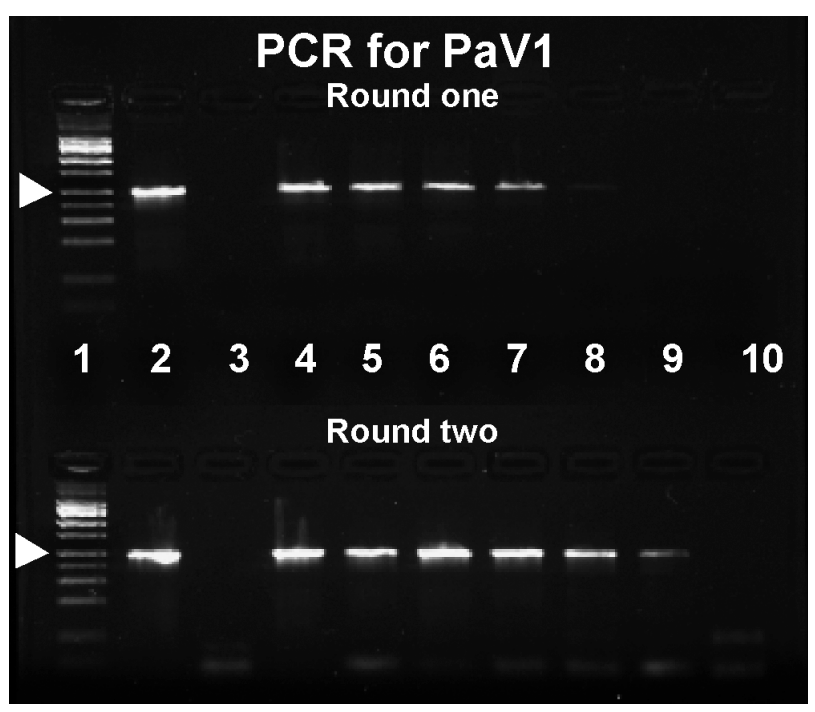

Fig. 1. Titration of purified PaV1 DNA shows that the PCR assay for PaV1 was highly sensitive. Lanes: 1, 100 bp ladder; 2, plasmid p892 positive control ${ }_{i} 3 \mathrm{ddH}_{2} \mathrm{O}$ control 4 to 10 , purified PaV1 DNA starting in Round 1 at $120 \mathrm{pg}$ and serially diluted 10-fold. $\$: 500 \mathrm{bp}$ marker

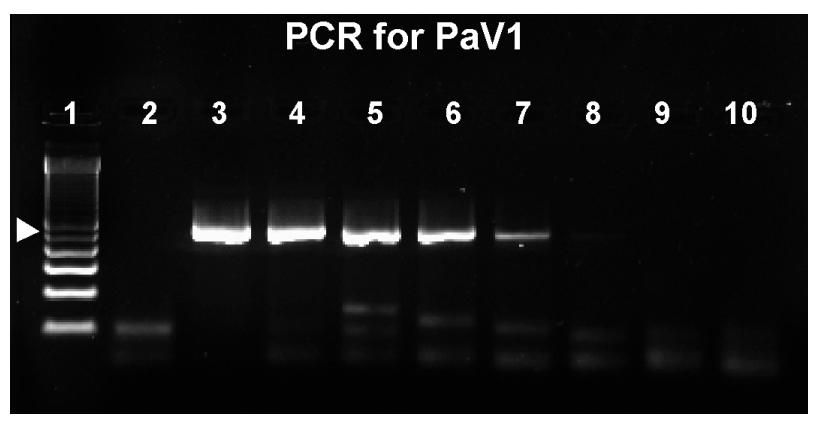

Fig. 2. Titration of genomic DNA from infected hemolymph shows that the PCR assay for PaV1 was highly sensitive. Lanes: 1, 100 bp ladder; $2, \mathrm{ddH}_{2} \mathrm{O}$ control; 3 , p892 positive control; 4 to 10 , genomic DNA from infected hemolymph starting at $12 \mathrm{ng}$ and serially diluted 10-fold. $\$ 500$ bp marker

the tissues infected with OsHV1 (Fig. 3A, Lanes 6 and 7), nor those infected with murine cytomegalovirus (Fig. 3C, Lane 4) produced amplicons in a Round 1 PCR assay for PaV1. Furthermore, PaV1 primers did not react with host oyster DNA (Fig. 3A, Lanes 4 and 5). Two specific PCR assays confirmed infection in these tissues; an OsHV1 PCR generated the expected 352 bp product from OsHV1 (Fig. 3B, Lanes 3 and 4) and the PCR assay for herpes virus DNA polymerase gave the expected band at $\sim 745$ bp (Fig. 3D, Lane 1).

The PCR assay for PaV1 detected viral infection in inoculated lobsters throughout the course of infection (Fig. 4). All of the lobsters were collected in the wild from Florida Bay populations and were thus subject to 

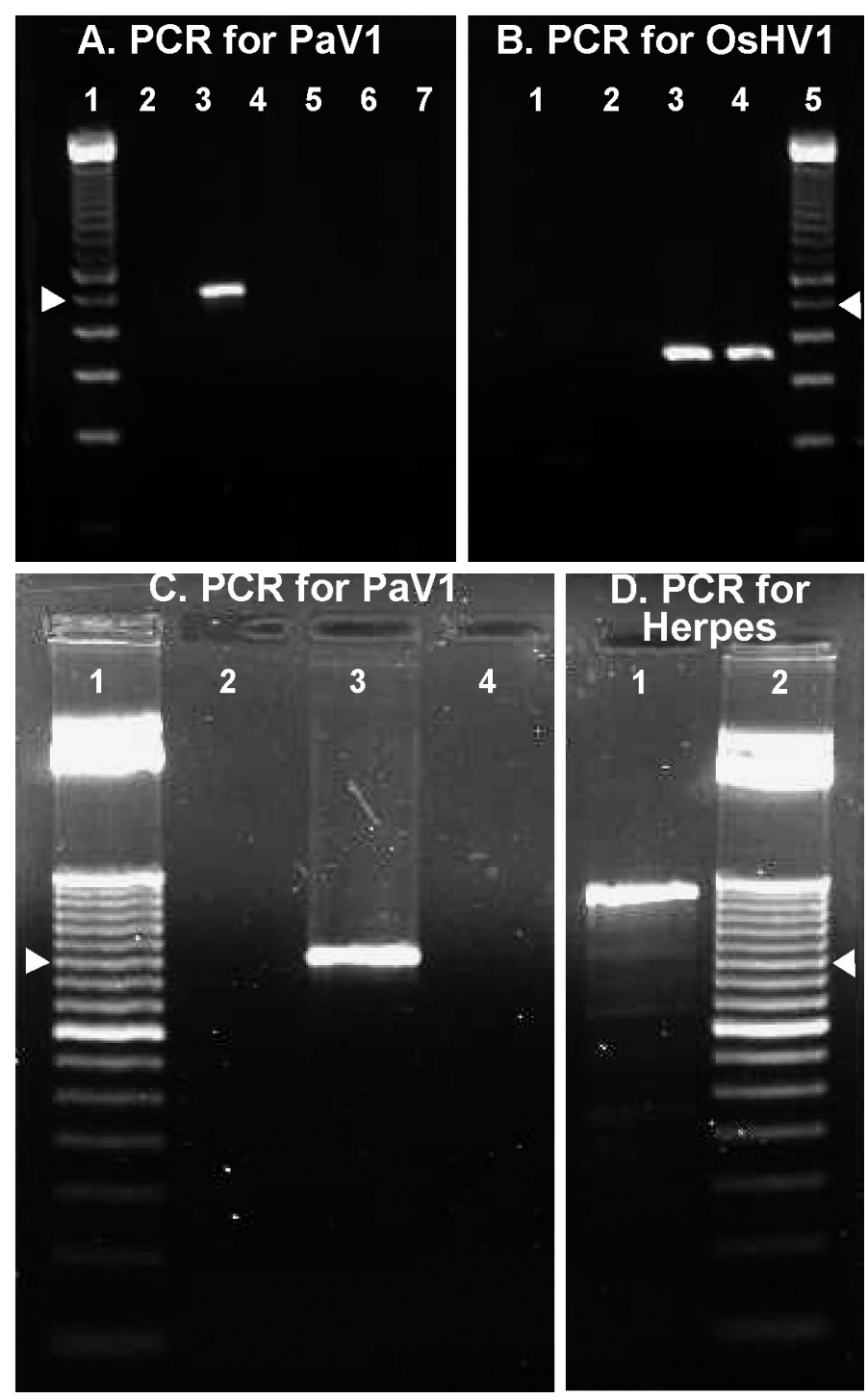

Fig. 3. The PCR assay was specific for PaV1. (A) PaV1 PCR tested against OsHV1-infected tissues. Lanes: 1, 100 bp ladder; 2, $\mathrm{ddH}_{2} \mathrm{O}$ control; 3, plasmid p892 positive control; 4 and 5, DNA from uninfected oysters $(1 \mu \mathrm{g}) ; 6$ and 7, DNA from infected oysters $(1 \mu \mathrm{g})$. (B) OsHV1 PCR tested against OsHV1-infected tissues. Lanes: 1 and 2, DNA from uninfected oysters $(1 \mu \mathrm{g}) ; 3$ and 4 , DNA from OsHV1-infected tissues $(1 \mu \mathrm{g}) ; 5,100$ bp ladder. (C) PaV1 PCR tested against murine cytomegalovirus. Lanes: 1, 50 bp ladder; $2, \mathrm{H}_{2} \mathrm{O}$ control; 3 , plasmid p892 positive control; 4, DNA from murine cytomegalovirus (20 ng). (D) Herpesvirus PCR tested against murine cytomgalovirus. Lanes: 1, DNA from murine cytomegalovirus (20 ng); 2, 50 bp ladder. ४: 500 bp markers

potential viral exposure under natural conditions; however, the 5 lobsters selected at representative points in the time course (Fig. 4A) showed no visible signs of infection immediately prior to inoculation and tested negative in the PCR assay for PaV1. A 499 bp band in the PCR assay for PaV1 indicates the presence of PaV1 at $10 \mathrm{~d}$ post-inoculation through $65 \mathrm{~d}$ post-inoculation
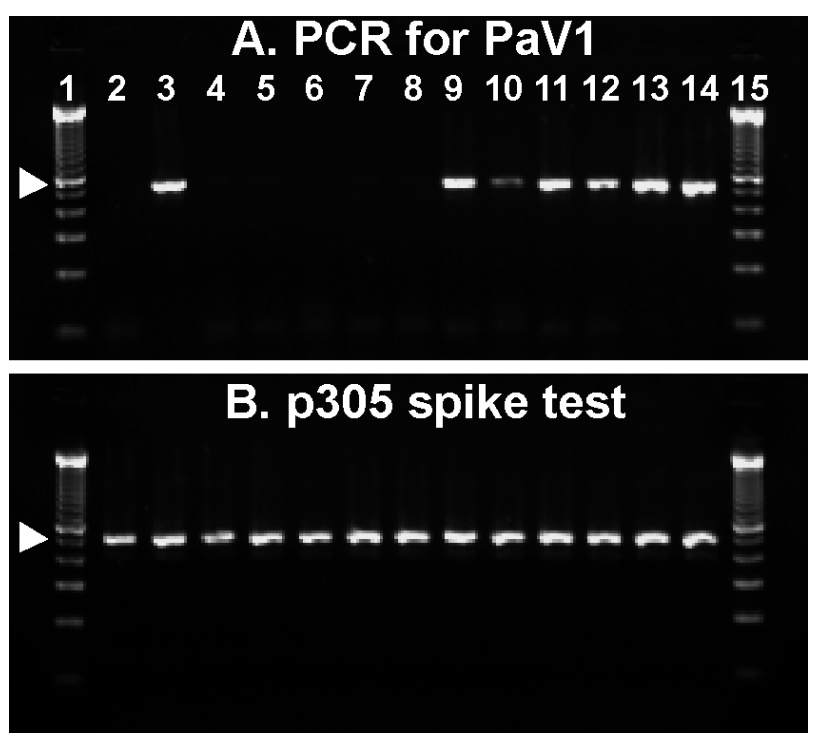

Fig. 4. Detection of virus in PaV1-inoculated lobsters. (A) The PCR assay for PaV1 detected viral infection during the entire incubation time from the onset of infection to the diseased state in the laboratory setting. Lanes: 1 and 15, 100 bp ladders; 2 , citrate anticoagulant; 3 and 14, plasmid p892 positive control; 4 to 8, pre-inoculation DNA from 5 lobsters; 9 to 13 post-inoculation DNA from each of the 5 lobsters collected on Days 10, 21, 45, 55, and 65 post-inoculation, respectively. (B) Plasmid spike test of the extracts used in Panel A shows that PCR inhibitors were not present in the reaction mixtures. Lanes: 2 to 14, the same extracts as for Panel A, except that $50 \mathrm{ng}$ of plasmid p305 was added and the corresponding M13 primers were used in each reaction. $500 \mathrm{bp}$ marker

(Lanes 9 to 13). Hemolymph was not acquired for PaV1 testing prior to Day 10, so detection may be possible even sooner after inoculation. The negative results for all of the pre-inoculation animals shown after two 30 cycle rounds of PCR further demonstrate that the PaV1 primers do not amplify host lobster DNA (Lanes 4 to 8$)$.

Overall, the PCR assay detected infection in $\sim 78 \%$ of inoculated lobsters (Table 2A,C), but assay detection rises to $94 \%$ if one includes the 3 lobsters that appeared to clear PaV1 from their hemolymph (Table 2B). The sample classified as 'inconclusive' (Table 2E) was

Table 2. PCR detection of PaV1 in 18 lobsters inoculated with infected hemolymph

\begin{tabular}{|lcc|}
\hline Pre- and post-inoculation result & Lobsters (N) & Percent \\
\hline A. Negative $\rightarrow$ Positive & 13 & 72.2 \\
B. Negative $\rightarrow$ Negative & 3 & 16.7 \\
C. Positive $\rightarrow$ Positive & 1 & 5.5 \\
D. Positive $\rightarrow$ Negative & 0 & 0.0 \\
E. Inconclusive & 1 & 5.5 \\
TOTAL & 18 & 100.0 \\
\hline
\end{tabular}


unusual in that the $499 \mathrm{bp}$ band produced in Round 1 failed to amplify in Round 2; this represents the single such incidence observed thus far. It is technically difficult to evaluate the PCR assay for PaV1 in terms of false-negative and false-positive readings, as there are no methods that can absolutely confirm the absence of virus in wild-caught lobsters and confirming infection by electron microscopy would require substantial effort to detect low level infections. However, all healthy hemolymph samples spiked with virus tested PCR positive, and repeated tests of PCR-negative samples were consistently negative.

The genomic DNA extraction procedure removed PCR inhibitors from the sample (Fig. 4B). The $481 \mathrm{bp}$ band from the spiked plasmid p305 shows that Taq polymerase, in the presence of hemolymph extracts, was fully functional and could generate amplicons from the plasmid. The results of the spike test also indicate that the PCR assay for PaV1 is not readily susceptible to false-negative readings originating from sample processing.

Because purified virus and laboratory-maintained inoculated lobsters were used to set up the PaV1 screening assay, it was necessary to test hemolymph samples from both healthy and diseased lobsters from the Florida Keys where natural infections are prevalent (Fig. 5). Twelve field-collected samples were selected because they showed a distribution of band intensities from a typical PCR screening effort; negative in Rounds 1 and 2 (Lanes 4 to 7), low-intensity
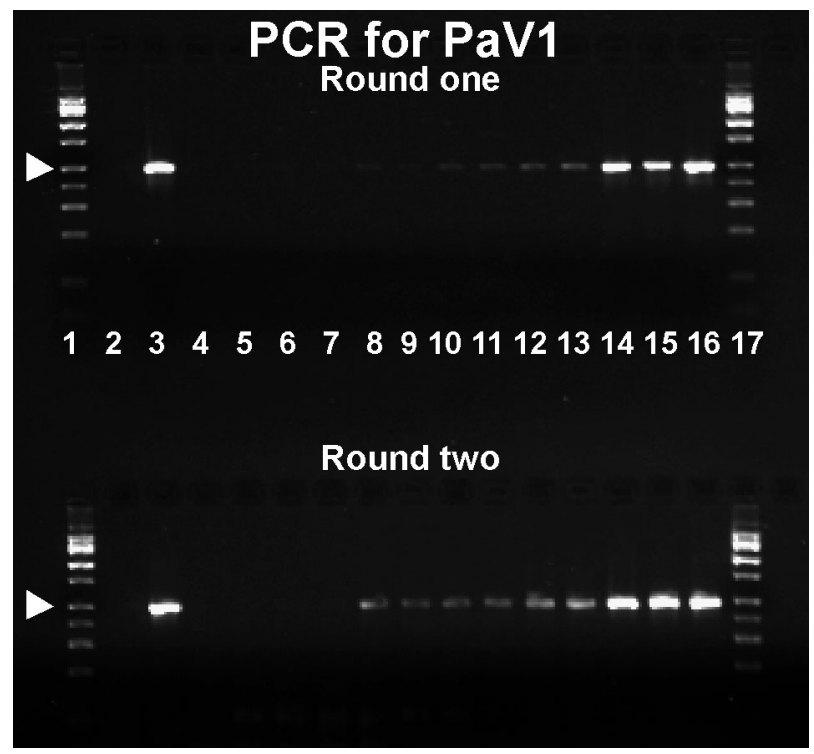

Fig. 5. The PCR assay for PaV1 detects the presence of PaV1 in naturally exposed lobsters. Lanes: 1 and 17, 100 bp ladders; 2 , citrate anticoagulant; 3 and 16, plasmid p892 positive control; 4 to 15, twelve lobsters collected from the Florida Keys.

D: 500 bp marker
499 bp bands in Round 1 that were amplified in Round 2 (Lanes 8 to 11), and strong bands in both rounds (Lanes 12 to 15). The lobsters shown in Fig. 4 were collected at different times and from different locations in 2003. Considering that lobsters from 2004 had similar patterns (not shown), the results indicate that the PCR assay for PaV1 detects a stable viral marker and thus can be used to screen wild-caught or laboratory lobsters for infection.

\section{DISCUSSION}

We have developed the first PCR-based assay for the detection of a lobster-specific virus. The PaV1 primers were selected from an $892 \mathrm{bp}$ sequence that was cloned from purified virus in a related PaV1 project (R. E. Ratzlaff unpubl. data). The PCR assay can be used to screen live lobsters Panulirus argus, both inoculated and naturally infected, using a relatively small volume of hemolymph $(20 \mu l)$; it thereby poses negligible risk to the lobster. The virus was detectable within $10 \mathrm{~d}$ of inoculation (at a minimum) and throughout the course of infection in hosts inoculated in a laboratory setting. Purified DNA from PaV1 was detectable from as low as $1.2 \mathrm{fg}$, though the number of virions this represents cannot be calculated until the size of the PaV1 genome has been determined. For a general comparison, a koi herpesvirus PCR with a sensitivity of $10 \mathrm{fg}$ was estimated to detect 30 virions (Bercovier et al. 2005).

Based on the testing of hemolymph samples, the PCR assay for PaV1 conclusively detected infection in $78 \%$ of inoculated lobsters; furthermore, the detection of virus would be $94 \%$ if host resistance to PaV1 was clearly established. The assay was developed for the testing of unclotted hemolymph samples, but, in preliminary experiments, the PCR assay detected PaV1 in extracts of clotted hemolymph and the hepatopancreas (data not shown). To the extent that we were able to evaluate specificity, the PCR assay for PaV1 did not react with lobster DNA, oyster DNA, OsHV1, or murine cytomegalovirus. Direct tests of other viruses have not been done; however, a BLAST search found that there was no significant similarity between the sequences of our PaV1 primers when compared with the genomic sequences of several putatively related viruses: OsHV1 (Herpesviridae), Frog Virus 3 (Iridoviridae), Singapore Grouper Iridovirus, Lymphocystis Disease Virus 1 (Iridoviridae), or Shrimp White Spot Syndrome Virus (Nimaviridae).

With regard to the handling of hemolymph samples, there are at least 3 sources of inhibition that necessitate stringent quality control measures to ensure the removal of inhibitors during the preparatory steps. Lobster hemolymph without anticoagulants and the 
anticoagulants themselves can inhibit the PCR reaction. We used 2 anticoagulants successfully in the present study: sodium citrate/EDTA (Söderhäll \& Smith 1983) and lobster salt solution with EDTA (Hernández-López et al. 2003). Both inhibit PCR, likely due to their EDTA content, but both anticoagulants can be removed from the sample DNA in the extraction process. Genomic DNA sample volumes $>10 \mu \mathrm{l}$ showed significant inhibition in the p305 plasmid spike test, possibly due to trace amounts of denaturing agents from the DNA extraction kit. However, with quality-control measures in place, the PCR assay for PaV1 was a reliable and sensitive test for the detection of viral infection in lobsters.

The PCR assay was developed to screen lobsters for $\mathrm{PaV1}$, and we have attempted to address the key step in this process, that is, the criteria used to determine the infection status. Ultimately, infection must be determined objectively by viewing PCR bands of varying intensities. A 2-round, low-cycle-number PCR assay was useful for discriminating very weak-intensity band artifacts in the small percentage of samples that posed a problem for interpretation. We observed 3 such instances in the $>100$ samples tested, and the bands were always of very low intensity and all failed to amplify in Round 2. Thus, the standard for assignment of PCR-negative status is either the absence of $499 \mathrm{bp}$ bands in Round 1 or the failure of weak bands to amplify in Round 2. We observed only 1 inconclusive sample, which showed a strong 499 bp band in Round 1, but, for unknown reasons, failed to amplify in Round 2. PCR-positive lobsters were assigned to 1 of 2 general categories: those with low-intensity $499 \mathrm{bp}$ bands in Round 1 that were amplified in Round 2 and those with strong bands in both rounds. The intensity of the bands was not easily attributed to the total amount of DNA in the hemolymph extract, although non-infected lobsters tended to yield less DNA. From a larger set of comparable samples $(\mathrm{N}=73)$, the DNA levels in the PCR assay were $16 \pm 9,31 \pm 30$, and $24 \pm$ $18 \mathrm{ng}$ (SD) for negative, low-intensity, and strong 499 bp bands, respectively. In spite of this variability, it is possible that hemolymph DNA levels rise with the spread of the virus within the host and drop as hemocytes are destroyed. Therefore, our preliminary conclusion, in the absence of more quantitative data, is that the intensity of the $499 \mathrm{bp}$ PCR band reflects the viral load in infected lobsters.

This study represents the second molecular detection assay developed for PaV1. A highly sensitive and specific FISH assay (Li et al. 2007), that can be used to assess the tropic nature of PaV1 in host tissues, should prove useful in characterizing the development of the disease process in lobsters. The advantage of a PCR assay for PaV1 lies in its ability to detect infections that may not be associated with pathology. Additionally, it allows for non-destructive assessment and monitoring of the prevalence and progression of infection in the fishery, as demonstrated by the laboratory trial and analysis of field isolates. The future application of both molecular techniques should help us understand the underlying nature of the disease caused by PaV1.

Acknowledgements. This work was supported by NOAA, Saltonstall-Kennedy Program Grant No. NA17FD2366 and an NSF Biological Oceanography Program Grant No. OCE0136894. We thank M. Butler, D. Behringer, and the staff of the Florida Fish and Wildlife Conservation Commission for help with sample collection. C. Li, A. Miller, and K. Wheeler maintained and cared for the lobsters at Virginia Institute of Marine Science. W. Hynes provided technical advice on PCR development, and C. A. Eaves and K. Griffin helped with DNA extractions at Old Dominion University. A. Campbell (Eastern Virginia Medical School) provided murine cytomegalovirus.

\section{LITERATURE CITED}

Batista FM, Taris N, Boudry P, Renault T (2005) Detection of ostreid herpesvirus-1 (OsHV-1) by PCR using a rapid and simple method of DNA extraction from oyster larvae. Dis Aquat Org 64:1-4

Behringer DC, Butler MJ, Shields JD (2006) Avoidance of disease by social lobsters. Nature 441:421

Bercovier H, Fishman Y, Nahary R, Sinai S and 5 others (2005) Cloning of the koi herpesvirus (KHV) gene encoding thymidine kinase and its use for a highly sensitive PCR based diagnosis. BMC Microbiol 5:13-21

Corbett Y, Herrera L, Gonzalez J, Cubilla L and 5 others (2004) A novel DNA-based microfluorimetric method to evaluate antimalarial drug activity. Am J Trop Med Hyg 70:119-124

Elhers B, Ulrich S, Goltz M (1999) Detection of two novel porcine herpesviruses with high similarity to gammaherpesviruses. J Gen Virol 80:971-978

Hernández-López J, Gollas-Galván T, Gómez-Jiménez S, Portillo-Clark G, Vargas-Albores F (2003) In the spiny lobster Panulirus interruptus the prophenoloxidase is located in plasma not in haemocytes. Fish Shellfish Immunol 14:105-114

Li C, Shields JD (2007) Primary cell culture of hemocytes from the spiny lobster and their susceptibility to Panulirus argus virus 1 (PaV1). J Invertebr Pathol (94:48-55)

Li C, Shields JD, Small HJ, Reece KS, Hartwig CL, Cooper RA, Ratzlaff RE (2007) Detection of Panulirus argus Virus 1 (PaV1) in the Caribbean spiny lobster using fluorescence in situ hybridization (FISH). Dis Aquat Org 72:185-192

Shields JD, Behringer DC Jr (2004) A new pathogenic virus in the Caribbean spiny lobster Panulirus argus from the Florida Keys. Dis Aquat Org 59:109-118

Smilkstein M, Sriwilaijaroen N, Kelly JX, Wilairat P, Riscoe M (2004) Simple and inexpensive fluorescence-based technique for high-throughput antimalarial drug screening. Antimicrob Agents Chemother 48:1803-1806

Söderhäll K, Smith VJ (1983) Separation of the haemocyte populations of Carcinus meanas and other marine decapods, and prophenoloxidase distribution. Dev Comp Immunol 7:229-239 